\title{
INFLUENNCE OF THE ROLES OF THE CSOs, HEADTEACHERS AND DEPUTY HEADTEACHERS IN SUPERVISION OF CURRICULUM IMPLEMENTATION IN CLASS FOUR IN PUBLIC PRIMARY SCHOOLS IN RONGO SUB-COUNTY KENYA
}

\author{
Mr. Joshua Olela Ochieng ${ }^{1 *}$, Dr.Collins Ogogo $^{2}$, Proffessor. Florence Odera ${ }^{3}$. \\ *1,2,3 RONGO UNIVERSITY
}

*Corresponding Author: -

\begin{abstract}
: -
Supervision of teaching and learning in public primary schools in one of the most important functions of the Ministry of Education in Kenya. The ministry appoints the Quality Assurance and Standards Officers to monitor the quality of Education in schools.

The Teachers Service Commission (TSC) also appoints the Curriculum Support Officers (CSOs) to monitor the quality of teaching and learning in schools. The main work of those two from the Ministry of Education and the Teachers Service Commission is to supervise the actual teaching and learning in Public Primary School. However, in recent years instructional supervision seems not to have been given a great deal of attention because the academic performance in schools and especially in class four which is a transition class from lower primary to upper primary has been very low in Rongo Sub-County.

Few research studies have been carried out or conducted towards the dismal or poor performance of class four in Public Primary Schools in Rongo Sub-County. This study was uncured on General System theory by Von Bettalafy 1956. The study was guided by one objective that states: The influence of the roles of the supervisors in supervision of curriculum implementation in class four in public primary schools in Rongo Sub-County. The study adopted a descriptive survey design. The purpose of the study was to investigate the influence of the supervisors' roles in the supervision of curriculum implementation in class four in public primary schools in Rongo Sub-County. The larger population was 603 whereby 74 were headteachers, 80 deputy headteachers, 444 class four teachers and 5 C.S.O. A sample size of 72 head teachers, 78 deputy headteachers, 133 class four teachers and 5 CSO (Curriculum Support Officers).

Saturation sampling was used on head teachers, deputy head teacher and CSO, while random sampling was used on class four teachers because the number was more. Data was collected by the use of questionnaires for deputy head teachers and class four teacher and in-depth interview scheduled was used to collect data from CSO and head teachers. The data collected was analyzed through the use of descriptive statistics and according to themes. From the study it emerged that the roles of the supervisors in the supervision of curriculum implementation has a great influence in the implementation of curriculum. It was also established that the supervisors does not give attentions to class four being especial class of transition from lower Primary to upper primary.

They rarely supervise the teachers handling class four and they even do not check the pupil's books. The CSO major in the lower classes for the programme of TUSOME and EGMA which are new methods of teaching reading and new mathematics. The study therefore recommended that the supervisors give attention to class four being that it's a class where there is change on medium of instruction from the language of the catchment to English and Kiswahili.
\end{abstract}

\section{(ㅇ) $(\$)$}




\section{INTRODUCTION}

Improving quality of Education in primary schools and the achievement of the learner remains apriority throughout the world, not least in the developing countries. To monitor quality, the national authority relies strongly on the school supervisors to achieve it (IIEP, UNESCO 2007).

According to UNESCO (2008) there has been a remarkable enrolment in schools; however, filing the classroom is not enough. It should have a positive social and economic consequences. It must involve the children learning at least the basic minimum competencies of literacy and numeracy that will enable them to benefit from and contributes to their society effectively. Unfortunately, evidence has accumulated to suggest that most learners especially in class four which is a transition class and a special class in the sense that there is change in language of instruction from language of the catchment area to English and Kiswahili are not able to handle tasks within their land. This can be seen in the table showing the zonal end term examination result. The result shows that they have been performing poorly for the four consecutive years. This result may have come as a result of very many factors one of them being the influence of the roles of the supervision in the implementation of curriculum.

Vision 2030 in Kenya recognized that Education for all Kenyans is fundamental to this success of the vision. In order to realize the national development goals, relevant and quality of education and training is required to meet the human development needs of the rapidly changing educational need and the diverse economy (Republic of Kenya 2000). Supervision of instruction has the potential to improve the classroom practices and hence contributes to learner success (Blasé and Blasé 2000).

Supervision is viewed as a cooperative venture in which supervision and the teachers engage in a dialogue for the purpose of improving instruction to pupils improved learning and success. ( Sorgiovantros \& Starratal 2012). To achieve the objectives of supervision, the supervisors of instruction should generally advice, inspect, control, evaluate assist and support teachers (IIEP

UNESCO 2008)

According to (Kamindo, 2006) as cited in Likwop Paul Kipngetich in the influence of headteacher rules in supervision for effective implementation of curriculum, he argued that for any organization to work effectively and achieved a desired goal or objectives, a system directed towards guidance and assistance of all those concerned with the realization of the set objectives must be put in place. Graliure, (2001) states that supervision is a key tool to ensure that all education staff respects the same rule and regulations followed as similar programs.

A study in Nigeria by Oghuubu (2001) established that the roles of the supervision as effective school inspectors of instruction should have regular workshop to enable them discharge their instructional supervision roles.

According to Fisher (2005), supervision helps in the organization and implementation of curriculum programs for learners. This view is shared with a Chesonal Smith (2011) he argues that an instructional leader should emphasize the process of instruction and facilitate interaction of teachers' pupils and curriculum.

Dakar framework for Action (2000) states that it's through teaching and learning process that brings the curriculum to life and determines what happens in the classroom and subsequently the quality of teaching and learning outcome.

The instructional supervisors have a role to select and produce instructional materials which help the teachers to perform their duties better and improve instruction through effective instructional leadership, Mbiti (1999), support this by arguing that its contented that the success of every school's curriculum design depend on a great extent on the administrator. As school supervisors the head teacher should make leading possible by stimulating desired changes in the professional behavior of the teachers, effective instructional supervision demand that he/she must be a competent teacher of the curriculum and should keep as to recent changes in curriculum and supervision in particular.

The supervisors should also ensure appropriate monitoring of pupils progress which entails continuous evaluation and feedback. This will lead to good performance linked to effective curriculum implementation.

According to Pollard (2002) effective supervisors are firm and purposeful, appoint effective teachers; create consensus and unity or purpose. The roles of the supervision must in one way or the other have an effect or influence in the supervision of curriculum. Supervisor should also ensure that appropriate monitoring of pupils performance or progress which entails continuous evaluation and feedback, this will lead to good performance lined to the effective curriculum implementation.

According to Pollard (2002), effective supervisors are firm and purposeful appoint effective teachers, create consensus unity or purpose. The role of the supervisor must in one way or the other have effect of influence on the supervision of curriculum.

One of the critical challenges facing primary school education in Rongo Sub-county is how to improve the quality of education that is teaching and learning in public primary schools. There has been a serious concern about the prior performance of class four in public primary school concerns regarding the improvement of the quality of teaching and learning are central to broader question of improving the quality of education UNESCO 2007.

Despite the government having injected a lot of funds in schools supervision by training head teachers curriculum support officer and the deputy headteachers on supervision the performance of the learners especially in class four is still very poor as can be seen in table 1.1 in the introduction part of class four zonal exam result for four consecutive years.

The purpose of this study is to find out or to establish the influence of the roles of the supervisors

CSOs, head teacher and deputy head teacher in the supervision of curriculum implementation in Public Primary Schools in Rongo Sub-County Migori County Kenya.

Objective examine the influence of the roles of the CSO, Head teacher and the deputy head teacher in the curriculum implementation and the research question was 'What are the influences of the roles of the instructional supervisions CSO, head teachers and the deputy head teachers in supervision of curriculum implementation?' 
This work is built on general system theory (Betalanfy 1956), the general system theory was developed in $20^{\text {th }}$ century and revised in 2004 and 2013 consecutively by academy of management in USA. This theory is used widely in various fields such as business, industry and education. This theory relates well educational organization.

According to general system theory, a system is a set of things or parts forming a whole of a complex unit, formed with many often diverse parts / subjects to a common plan or goal or purpose (Kothari, 2005). The Ministry of Education is formed of many parts or levels or sections among them are the internal supervision headed by the Quality Assurance and Standards of the office and the internal supervision headed by the school administrators their subjects are majorly to implement the intended curriculum for the achievement of intended skills, knowledge and attitude which are necessary for the learners in life.

The system theory views the entire educational organization as a complex organization of different parts that are highly interrelated and independent. In a school the CSOs, the headteachers and the deputy head teachers and the teachers must work in harmony to achieve the intended educational goals and objectives. Each person need to know and understand what causes place at each level and know the responsibility of every level and know the responsibility of every level and all these levels need to work in harmony of the knowledge, skills and attitudes as intended by the curriculum designers. Every level works to contribute to a whole for the supervision to achieve a harmonious relationship with the supervisors they must has the skills, knowledge and attitude through training, the curriculum support officers must work closely with the headteachers and the deputy head teachers to help supervise the work done by the teachers in classes in order to achieve quality education, the curriculum support officers work on behalf of the Teachers Service Commission which is the teachers employer in Kenya while the head teachers, deputy head teachers represent the ministry through the Teachers Service Commission.

\section{REVIEW OF RELEVANT LITERATURE}

Research conducted in developed countries like America and Britain reveals that supervision of instruction is a very important aspect in the education because it reveals what takes place in the classroom set up. Several researchers have come up with definition of instructional supervision. Cohen, (2001) defend instructional supervision in primary school as a professional service involving the relevant educational administrator for the purpose of interacting with the teacher in such a way as to create change and improve the provision and actualization of learning opportunities for the pupils.

Other researcher have defend instructional supervision in several terms but almost all of them seem to be contradicting on a common aim and objective. The main aim of instructional supervision is to improve teachers instructional practices which may intern improve students learning outcome. Ochiang (2007) proposed that the focus on instructional supervision is to provide teaches with information about their teaching so as to develop instructional skills to improve performance. Further Boline and Panaretus, (2004) views cited by Mary (2011) and Peter and Belfour (2014) stated that the primary purpose of supervision is to help and support teachers as they adopt and refine instructional practices, they are trying to implement in their classrooms.

Similarly instructional supervision is seen as a set of activities designed to improve the teaching and learning process Holly and Forsyth 1986 argue that the purpose of instructional supervision is neither to judge the competency of the teachers nor to control them but rather to work comparatively with them because some teachers are more experienced and more informed and even better teachers plan their supervisors.

According to Wanzare (2012) instructional supervision embraces all activities that are directed especially towards establishment, maintenance and improvement of teaching and learning in schools.

According to Wanzare,(2015) instructional supervision on the other hand is concerned with holding staff meetings, provision of teacher development, checking of teachers professional documents, checking of pupils exercise books, holding model teaching lessons, provision of enough teaching and learning materials and classroom observation among other responsibilities or activities undertaken to help the teachers maintain and improve their effectiveness in the classrooms.

Kothari, 2005 defines instructional supervision as that part of instruction which draws its data from the first-hand information or observation of actual teaching event and involve face to face (and other associated interactions) between the supervisors and the teacher in the analysis of teaching behavior.

\section{Effective supervision}

Many researches have conceptualized effective supervision as an end result or product and as the collection of knowledge and skills that supervisor's process. Gordon and Ross Gordon (2004), argues that effective supervision requires welltrained personnel. In the case of curriculum implementation, the curriculum support officers (CSO), the head teachers and deputy head teachers should be properly trained in the supervision of curriculum. The government should appoint curriculum support officers who are specialized in curriculum so that they can be able to support the teacher in curriculum delivery. They should have the knowledge of curriculum and good interpersonal relationship for effective supervision and curriculum implementation.

According to Glickman Gordon (2004) three personal attribute are applied through the supervisory roles of direct assistance to teachers group development, professional development curriculum development and action research.

To facilitate effective supervision process, Glickman Gordon and Ross Gordon (2004) proposes that supervisor should perform the role of providing personal development by providing ongoing contact with the individual teachers to be observed and assist him/her in classroom observation for professional development by providing the learning opportunities for the faculty provided or supported by the school and the school system. 
Similarly supervisors should support curriculum development through the vision and modification of content, plan and material of classroom instruction. Supervisors should also encourage teachers on action research by systematically studying faculty to find out what is happening in the classroom and school with the aim of involving learners learning. Other researches share the same opinion or view as those upheld by Glickman and Sullivan,

2006 who believes that an effective supervisor (i.e. head teacher, deputy head teacher and the CSO should possess good interpersonal relationship with other teachers.

Blasé and Blasé (1999) proposes a model of effective supervision derived from data finding which consists of two major themes talking with teachers to promote reflection and promoting professional growth. According to them, effective supervisors value dialogue that encourages teachers to critically reflect on their teaching and professional practices through making suggestions, giving feedbacks, modeling inquiry aid soliciting pieces of advices and opinion and giving praise.

They also argue that effective supervisors use six strategies to promote teachers professional growth; emphasizing the study of teaching and learning supporting collaboration effort among educators, developing, coaching, relationships among educators, discouraging and supporting resigning of programs applying principles of adult learning growth and development to all faces of staff development and implementing action research to inform institutional decision making. Other researchers believe that effective supervisors are those who link interpersonal skill with technical skills. Brenner, (2008) argue that effective supervisor who link interpersonal and technical skill will be successful in improving instructors. He suggests that effective supervisor should be able to build self-acceptance moral, trust and support between the two parties. He reports that effective supervision should not develop deeply into the roles of counsellor but the forecast should always be on the teaching act. It's for this reason that Brenner, (2008) argues that effective supervision is realized when supervisors clearly defined or set out the criteria to be used in the evaluation process and ensure that even the final assessment is a negative one, the teachers will benefit from the exercise and leave with his/her self-esteem intact.

The ideas of supervision has been around for a long time but the systematic study of it is more recent. To comprehend modern supervisory techniques, it's important to trace its trends from the developed countries and review the development of supervision in Kenya and how their roles affect supervision of curriculum implementation in class four being a special class of transition from lower to upper primary.

\section{Supervision of schools in Kenya}

The history of supervision of schools in Kenya dates backs to 1910 when colonial government established an educational department responsible for the supervision of all matters related to education.

The Europeans and Asians were primarily given professional education while the Africans were given more technical oriented education (Ominde commission, 1964).

In 1925, the white paper produced by the Advisory Committee on the indigenous education (ACIE) indicated that effective or through system of supervision was indispensable for the functionality of efficiency of the educational system. The paper also advice that each mission should be encouraged to developed a system for the effective supervision of its own schools. By 1927 the system was operational and inspectors were fully paid government workers. In 1949 the government appointed a committee under Archdeacon L.J. Beacher recommended strict supervision and inspection of primary schools.

Bins reports of 1952 advocated the strengthening of the supervisory and inspectorate system and advocated for merging of supervision and inspection. (Republic of Kenya 1964) emphasized the importance of supervision when it stated that a good system of supervision was essential to any school system and was particularly important when a large position of teachers was without adequate training. It recommended the establishment of one education officer for hundred schools to strengthen supervision. It further recommended that supervisors should be carefully selected, trained and relieved of administrative duties.

Ndegwa Commission of 1970 recommended that the inspectorate system of primary education needed an urgent overhaul because the inspectorate had remained the same in its approach to supervision of schools as it was in the colonial days. The Kenya education commission. Republic of Kenya policy guide line on supervision wanted to ensure quality and relevance in the growth and provision of education in the country. It recommended the strengthening of school supervision and ration of one inspector to thirty schools. To support this, the government decentralized inspectorate department to zones, where these days we have curriculum support officers they are in-charge of zonal from the teacher's service commission while from the ministry of education there are Quality Assurance and Standard Officers (QASOs). They are incharge of quality teaching and learning in schools.

The government of Kenya regards supervision of schools central to effective teaching and learning and has therefore unlevered to provide supervisors with necessary facilities to expedite supervision.

In the early years, the supervisors were acting as administrators and were only interested in the curriculum, but not how the teaching was done (Kothari 2005). This has undergone several changes and the school administrators have also been charged with supervisory roles in schools. The head teacher, the deputy head teacher and the senior teachers do take part in supervision of curriculum implementation. This has made supervisors most effective in improving the curriculum implementation.

In 2015 the teachers service commission (TSC) strengthened supervisory activities in schools by introducing the Teacher Performance and Appraisal (Performance contract) TPAD. The TSC directed the Curriculum Support Officers to liars with head teachers and the deputy head teachers to strengthen supervision by giving the appraisal report termly to monitor the work of curriculum implementation in schools. The government even promised to offer extra allowance so that the supervisor could be thorough (Daily Nation Friday $6^{\text {th }}$ April 2017) 
In recent years, several measures have been taken to a certain successful and effective supervision on instruction. This paper is trying to investigate the influence of the roles of the supervisors in curriculum implementation.

\section{Influence of the roles of the supervisors in curriculum implementation in class four in public schools Head teacher}

The head teacher is regarded as an internal supervisor on behalf of both the ministry of education and the teachers' service commission. Owuko 2004 pointed out that the curriculum support officers are supposed to offer technical guidance to head teacher to enable them perform their supervisory duties in school effectively. Kamindo (2006) highlighted that though head teachers are the immediate supervisor in schools, they are not well prepared for the task. The head teachers are involved in the translation of educational policies and objectives into programs within the school programs. They are expected to possess superior knowledge about curriculum and instruction to provide expert leadership in all areas of school programs. This seems not to be true as stated by Owuko 2004.

Olembo, (1992) reported that the head teachers clerical and teaching duties been reduced and emphasis have been put on the supervisory rules in school. The head teacher should be a teacher of the leading staff so as to influence leading activity in the school.

$\mathrm{He} /$ she is supposed to observe the class-room work and asses the performance and pupil's achievement. He is supposed to provide motivation to teachers and learners to enhance order in school among teacher, learners, parents and the subordinate staff. He is also supposed to promote staff professional development need and address them by running schools based in-service training (INSET) programs

As financial controller, the head teacher must ensure proper budgeting and accounting. It is accountable to all expenditure and must ensure that books of account are kept up to date. Other responsibilities or roles of the head teacher as an instructional leader include:- creating a conducive atmosphere or environment to facilitate supervisory activities in the school by organizing all necessary resources, giving professional assistance and guidance to teachers to enable them realize the instructional objectives and supervising classes when he deem necessary, coordinating of evaluation of teachers and learning processes and the outcome through initiation of active participation of staff members and local community at large (Wanzare 2012).

\section{The deputy head teachers}

Besides assisting the head teacher in carrying out the above responsibilities, the deputy head teacher is expected to give overall headship to staff members, checking teachers' professional documents like the schemes of work, lesson plans registers, lesson notes and other documents. He is supposed to approve the professional documents and give correction where necessary for effective teaching and learning. The deputy head teacher is directly responsible for the implementation of curriculum and school discipline. He is also the staff secretary who keeps the school records. He is therefore, supposed to ensure that all the records of the school are in safe custody. He is also to check and ensure that the taught curriculum is in line with the need of the community. (Wanzare, 2013).

\section{Curriculum support officers (C.S. Os)}

Quality Assurance and Standards Officers (QASOs) work on behalf of the ministry of education to check the quality of teaching and learning while the CSOs work on behalf of Teachers Service Commission. These are very important persons in the Supervisory Work in our schools as pertains to the implementation of curriculum, the Curriculum Support Officers are responsible in promoting the quality of education in all schools through instruction of curriculum and staff development. They are supposed to have higher knowledge in curriculum than the head teachers and the deputy head teachers and to give direction and support to teachers (MOE, 2000). As pointed out by Wanga (2004), one of the roles of the CSOs, is to assist quality development services of teachers by organizing in-service training for teachers. Ozingi (2011) pointed out that the supervisors of schools must perform the task of curriculum instruction they are supposed to determine the goals and purposes, designing and develop courses or organizing learning activities, promoting changes and improvement of curriculum and instructions

According to Teaches Service Commission (TSC 2015) the role of the CSO are to assist the teachers to make teaching aids or material update teachers on curriculum changes, pedagogy content, coverage and any other emerging issue in the teaching service. Provide guidance and counseling to teachers and disseminate information on curriculum.

\section{RESEACH METHORD}

Descriptive survey design was used because the main intention of this work is to investigate the influence of the roles of supervisions in the implementation of curriculum in class four in public primary school in Rongo Sub-County. Open ended and closed ended questions were used in the questionnaires and interview schedules were used to collect data for this study. Descriptive survey design was thought necessary because Cohen (2007) point out that it help to gather data at particular point in time with the intention of describing the nature of existing condition or identifying standards against which existing condition can be compared or determining the relationship that exist between specific event. The research work was done in public school in Rongo sub-county in migori county Kenya. The school that the research work was done were 74 public primary school. 74 head teachers, 80 deputy head teachers, 5 CSOs and 444 class four teachers.

The researcher used saturation sampling on all head teacher and the deputy head teachers apart from those that piloting was done and saturation sampling for all Curriculum Support Officer (CSOs), while on class four teachers the researcher used simple random sampling and sampled 133 class four teachers out of 444 which represent $30 \%$ as advocated by Mugenda and Mugenda (2008). 
For the validity and reliability of research findings, the researcher sort the expertise of the supervisor for the validity of the tools, and test and re-test concept to test reliability of the research instruments. The data was collected using research instruments and analysis was done and the finding presented in table and bar as indicated in chapter four

\section{RESULTS}

The result of the questionnaire and interview scheduled are in the table and graphs as shown below. The result below also shows the demographic characteristics of the respondent. The purpose of the study was to investigate the influence of the roles of the supervisors in the supervision of curriculum implementation in public primary schools.

\subsection{Participants Response Rate}

The study used a sample population of 292.The questionnaires were administered to 213 respondents, 80 for deputy head teachers and 133 for class four teachers. The interview schedule was planned for 79 respondents where 74 were head teachers and 5 were CSOs and the response rate were summarized in the Table 4.1.

Table 4.1: Questionnaire return rate (Appendix I a and b)

\begin{tabular}{lccc}
\hline Categories & $\begin{array}{c}\text { Targeted } \\
\text { questionnaires }\end{array}$ & Returned rate & Percentage \\
\hline Deputy head teacher & 80 & 77 & $96.25 \%$ \\
Class four teachers & 133 & 130 & $97.74 \%$ \\
\hline Total & $\mathbf{2 1 3}$ & $\mathbf{2 0 7}$ & $\mathbf{9 7 . 1 8 \%}$
\end{tabular}

The researcher also used interview schedules to obtain more data from the CSOs and the head teachers on their views on the factors affecting supervision of curriculum implementation in class four in public primary schools in Rongo SubCounty. Table 4.2 shows how the interviews were scheduled and the actual interviews conducted.

Table 4.2: Conducted Interviews schedules (appendix II a and b)

\begin{tabular}{lccc}
\hline Respondents & \multicolumn{2}{c}{ Interviews } & $\%$ \\
& Scheduled & Conducted & \\
& & & 100 \\
CSO & 5 & 5 & 94.5 \\
Headteachers & 74 & 70 & \\
\hline Total & 79 & $\mathbf{7 5}$ & $\mathbf{9 4 . 9}$ \\
\hline
\end{tabular}

Response rate according to American Association for public Opinion Research (AAPOR), (2011), is the rate of complete research instrument with responding units divided by the number of eligible reporting units in the sample. A total of 80 questionnaires were distributed to the deputy head teachers and 133questionnaires to class four teachers which was $100 \%$, 77 questionnaires were returned representing $97.18 \%$. Seventy-nine interviews were scheduled and 75 were conducted that represented $94.9 \%$. According to Mugenda and Mugenda (2008), a response rate of 50\% is acceptable for analysis. AAPOR (2011), explained that a response rate of over a half is good while over $70 \%$ is very good. The response rate for both the questionnaire and the interview schedules were $97.18 \%$ and $94.9 \%$ respectively. This was considered to be very good. This was in line with Bobbie (1990) who stated that a response rate of $60 \%$ is good,

$70 \%$ is very good and $50 \%$ is adequate for analysis. Reporting from a manual survey, Bailey (1996), set the adequate bar at $75 \%$ and again, Chen (1996) argued that the larger the response rate, the smaller the non- response error. The rate at which the questionnaires were returned and the rate at which the interviews were conducted was considered by the researcher to be very high and satisfactory as compared to the finding of the other researchers as indicated above.

\subsection{Demographic and Background Information of the Respondents}

The study sought to find out the demographic and background details of the respondents. The background was important because it would give or reveal the ability and the qualification of the respondents in relation to the task bestowed on them and the data collected were analyzed and the result provided in table 4.3. 
Table 4.3: Respondents age bracket

\begin{tabular}{lllllllll}
\hline Respondent & CSO & \multicolumn{3}{l}{$\begin{array}{l}\text { Head } \\
\text { teachers }\end{array}$} & $\begin{array}{l}\text { Deputy } \\
\text { teachers }\end{array}$ & $\begin{array}{l}\text { head } \\
\text { Class } \\
\text { Teachers }\end{array}$ & Four \\
\hline $\mathbf{3 1 - 3 5}$ & $\mathrm{F}$ & $\%$ & $\mathrm{~F}$ & $\%$ & $\mathrm{~F}$ & $\%$ & $\mathrm{~F}$ & $\%$ \\
$\mathbf{3 6 - 4 0}$ & & & & & 2 & 2.9 & 3 & 2.3 \\
$\mathbf{4 1 - 4 5}$ & & & 6 & 8.6 & 52 & 74.3 & 76 & 58.5 \\
$\mathbf{4 6 - 5 0}$ & 3 & 60 & 34 & 48,6 & 8 & 11.4 & 31 & 23.1 \\
$\mathbf{5 1 - 5 5}$ & 2 & 40 & 3 & 42.9 & 15 & 21.4 & 20 & 15.4 \\
\hline Total & $\mathbf{5}$ & $\mathbf{1 0 0}$ & $\mathbf{7 0}$ & $\mathbf{1 0 0}$ & $\mathbf{7 7}$ & $\mathbf{1 0 0}$ & $\mathbf{1 3 0}$ & $\mathbf{1 0 0}$ \\
\hline
\end{tabular}

Table 4.3 indicated that 2 CSOs representing $40 \%$ were within the age bracket of $46-50$ and 3 representing $60 \%$ were within the age bracket of $51-55$. This showed that all the CSOs were mature enough to handle the task of supervision because they had enough experience considering their ages, the table also showed that 52 head teachers representing $70 \%$ were within the age bracket of 46-50 meaning that the maturity of the distribution of the cohort group had been reflected based on age hence had more experience in service in the teaching profession(TSC code of conduct) responsibilities of the head teachers and the deputy head teachers could allow them to take up their supervisory activities in schools. The deputy head teachers were also found to be more in the age bracket of $41-45$, this was representing $70 \%$ showing that they were also mature enough to handle their supervisory activities because according to the TSC act 2013, the deputy head teachers are the ones who are directly responsible for the implementation of the curriculum in schools. Among the class four teachers, 69 of them representing $53.1 \%$ were found to be in the age bracket of $41-45$ hence were mature and experienced enough to handle class four pupils following the time they have taken in service. The researcher further clarified this information on age bracket by the use of a bar graph as shown in the figure 4.1.

\subsection{Professional Qualifications}

The researcher sought the participants' professional qualification. The participants' professional qualification was considered important for this study because for one to work as a supervisor, one must possess or have a required professional qualification to do the work. The respondents were asked to state their highest academic qualification and the findings were presented and discussed on table 4.4

Table 4.4: Respondents' professional qualification

\begin{tabular}{|c|c|c|c|c|c|c|c|c|c|c|}
\hline \multicolumn{11}{|c|}{ Qualifications } \\
\hline & \multicolumn{2}{|c|}{ MED } & \multicolumn{2}{|c|}{ BED } & \multicolumn{2}{|c|}{ DIPLOMA } & \multicolumn{2}{|c|}{ P1 } & \multicolumn{2}{|l|}{ PHD } \\
\hline & $f$ & $\%$ & $\mathrm{f}$ & $\%$ & $\mathrm{f}$ & $\%$ & $\mathrm{f}$ & $\%$ & f $\%$ & \\
\hline Head teachers & 1 & $14 \%$ & 11 & $15 \%$ & 38 & $54.3 \%$ & 20 & $28.6 \%$ & - & - \\
\hline $\begin{array}{l}\text { Deputy head } \\
\text { teachers }\end{array}$ & - & - & 12 & $5.56 \%$ & 32 & $41.6 \%$ & 33 & $42.9 \%$ & - & - \\
\hline $\begin{array}{ll}\text { class } & \text { Four } \\
\text { Teachers } & \end{array}$ & & & 28 & $21.5 \%$ & 53 & $40.8 \%$ & 49 & $37.7 \%$ & & \\
\hline Total & 1 & & 51 & & 123 & & 10 & & & \\
\hline
\end{tabular}

The data from table 4.4indicated that all the participants excluding the CSOs had diploma and bachelors as their highest academic qualification. Forty-nine head teachers representing $70 \%$ indicated that their highest professional qualification is Diploma and above. Forty-eight deputy head teachers representing 70\% indicated that diploma and B.Ed are their highest professional qualifications and among the class four teachers, 81 of them representing $63.3 \%$ indicated that their highest professional qualification is diploma and above, head teachers and the deputy head teachers were professionally qualified to do their supervisory work and the class four teachers were also well qualified to handle the class four since they had properly been trained in P1 certificate course.

Babayemi (2006) pointed out that in order to carry out instructional supervision practices properly or effectively, the CSOs, head teachers and the deputy head teachers must be trained to improve their supervisory practices through intensified workshops and seminars. Kirui (2012) argued that the CSOs, head teachers and the deputy head teachers must not only be trained on teaching skills but also the skills of supervision that would help them in effective supervision of curriculum in class four. This information was further presented in the bar graph bellow for clarity. 
Figure 4.2: Respondents 'professional qualifications

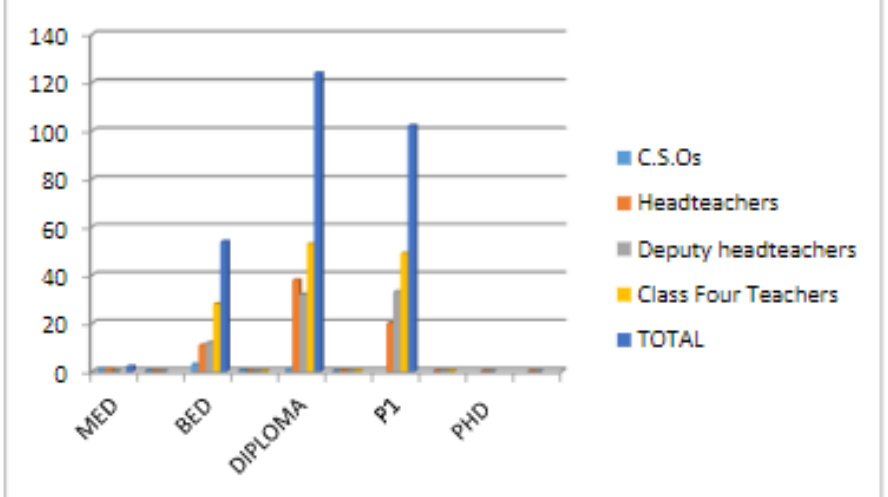

In another research finding the number of participants with masters was one and the others were as indicated in figure 4.2 above it showed clearly that the CSOs, the head teachers and the deputy head teachers are within the academic qualification of diploma and bachelor of education while only the CSOs had master degree and the rest had bachelors diploma and certificate and none had a PHD. These qualifications were strong enough to help the supervisors carry out their supervisory work because of the level of education they had.

\subsection{Respondents Teaching Experience}

The researcher then sought to find out the teaching experience of respondents This was considered important because one who has taken long in a given area is believed to have acquired enough skills, knowledge and attitude that would help him or her to perform better in supervision of curriculum than those who are new in the service as it's said that experience is the best teacher. The findings were presented in table 4.5 .

Table 4.5: Respondents teaching experience

\begin{tabular}{|c|c|c|c|c|c|c|c|c|}
\hline \multirow[t]{2}{*}{ Experience } & \multicolumn{2}{|r|}{ CSOs } & \multicolumn{2}{|c|}{$\begin{array}{l}\text { Head } \\
\text { teacher }\end{array}$} & \multicolumn{2}{|c|}{$\begin{array}{c}\text { Deputy } \\
\text { Head } \\
\text { teachers }\end{array}$} & \multicolumn{2}{|c|}{$\begin{array}{l}\text { Class } \\
\text { four }\end{array}$} \\
\hline & $\mathbf{f}$ & $\%$ & $\mathbf{F}$ & $\%$ & f & $\%$ & $\mathbf{f}$ & $\%$ \\
\hline $\begin{array}{l}\text { Below } 1 \text { year } \\
1-5 \text { years }\end{array}$ & & & & & & & 12 & 9.2 \\
\hline $6-10$ years & & & & & 5 & 6.5 & 32 & 24.6 \\
\hline $11-15$ years & & & 3 & 4.2 & 11 & 14.3 & 48 & 36.9 \\
\hline $16-20$ years & & & 25 & 32.9 & 52 & 67.5 & 14 & 10.8 \\
\hline Above 21 & 5 & 100 & 44 & 62.9 & 9 & 11.7 & 24 & 18.5 \\
\hline Total & 5 & 100 & 70 & 100 & 77 & 100 & 130 & 100 \\
\hline
\end{tabular}

Table 4.5 shows that 44 head teachers representing $62.9 \%$ had served for more than 21 years, 52 deputy head teachers representing $67.5 \%$ indicated that they had served between $16-20$ years and

9 of them had served for more than 21 years. This showed that they had gained enough experience to do their supervisory work because they had passed through what they were supervising. On the side of class four teachers, the table indicates that 118 class four teachers had served between 6-21 years and that again is a clear indication that they have enough experience to handle class four. To make the information clearer the findings were further presented in figure 4.3 to include findings from the CSOs

The findings are in line with Muchira (1995) who carried a study on constraints and challenges to effective primary school management in Eritrea. He found that limited experience had a great deal to do with administrative deficiencies observed in those with less than five years. This finding can be related to the case of supervision of curriculum implementation in primary schools. The supervisors should have enough experience as that guarantees competent supervisory knowledge and skills. 
Figure 4.3: Respondents teaching experience

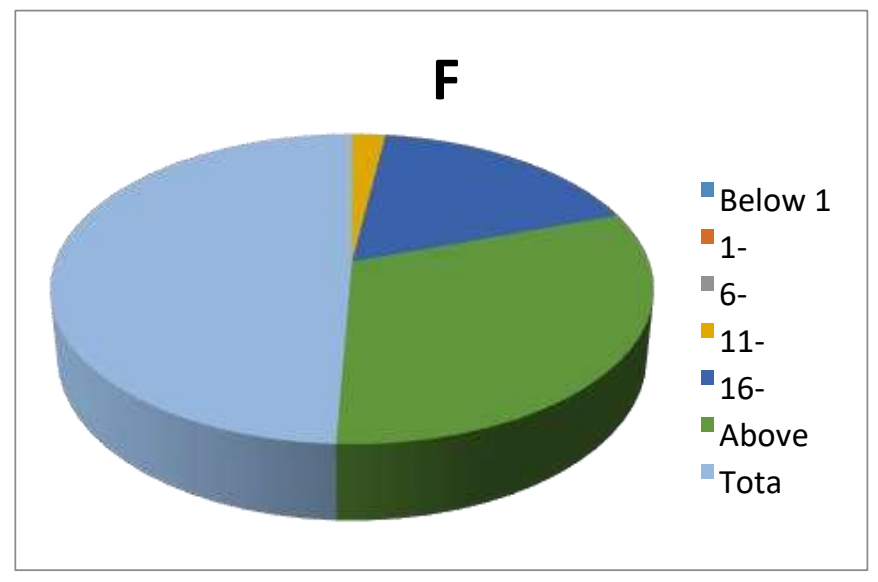

Figure 4.3 indicated that majority of the respondents had served for more than 21 years. This showed that most of the respondents had taken long in the teaching profession and hence had acquired enough experience that would help them perform the supervisory work and teaching. The CSOs had more experience than other respondents as can be seen in the figure above.

\subsection{Respondents In-Service Course}

The researcher sought to establish whether the respondents had attended any other course other than the basic from the teachers training college. This was considered important because education is dynamic in the sense that there are emerging issues that need to be incorporated into the system and this was only possible when one goes for further training on supervision of curriculum implementation to add value to what already exists. The findings were displayed in table 4.6.

Table 4.6: Respondents in-service course

\begin{tabular}{|c|c|c|c|c|c|c|c|c|}
\hline \multirow[t]{2}{*}{ Respondents } & \multicolumn{2}{|c|}{ CSOs } & \multicolumn{2}{|c|}{ Head teac } & \multirow{2}{*}{$\begin{array}{c}\text { Deputy } \\
\text { teachers } \\
\text { F }\end{array}$} & \multirow{2}{*}{$\begin{array}{c}\text { head } \\
\%\end{array}$} & \multicolumn{2}{|c|}{$\begin{array}{l}\text { Class four } \\
\text { teachers }\end{array}$} \\
\hline & $\mathrm{F}$ & $\%$ & $\mathrm{f}$ & $\%$ & & & $\mathrm{~F}$ & $\%$ \\
\hline Yes & 5 & 100 & 70 & 100 & 77 & 100 & 81 & 62.3 \\
\hline No & & & & & & & 49 & 37.7 \\
\hline
\end{tabular}

Table 4.6 indicated that almost all the respondents had attended an in-service Couse because all the CSOs representing $100 \%$, all the head teachers representing $100 \%$, all the deputy head teachers representing $100 \%$ and $62.3 \%$ of the class four teachers had attended other courses.

Only a small percentage (37.7) of the class four teachers had never attended any other in-service course apart from the P1 course. This was a clear indication that almost all the respondents had acquired enough knowledge and skills that would help them perform their supervisory duties in curriculum implementation. The findings are in line with Wangai (2007). He stated that there is need to have in-service courses to help the teachers attend well to the pertinent issues. Eshiwani (1993) argued that it's advisable for the supervisors to have seminars and workshops to improve knowledge and skills of the supervisors on educational emerging issues and methodology as this will improve the depth of understanding of the learners hence there is need for systematic upgrading of all the supervisors through long term or short-term seminars.

\section{Influence of the roles of Supervisors in Curriculum Implementation in class four.}

Through the questionnaires presented and the interview schedule handled by the investigator, he found that supervisors of the curriculum have several roles that they have to play for proper supervision of curriculum implementation. Some of the roles included; checking of the professional documents, classroom lesson observation, checking the pupils note books, checking class registers, teachers' progress records and provision of teaching learning resources. The researcher sought to know how these roles were being undertaken, how they influence the supervision of curriculum implementation in class four in public primary schools in Rongo Sub County and the frequency of the supervision of curriculum implementation and the findings were analyzed and tabulated bellow.

\section{Checking of Teachers Professional Records}

The investigator sought to know whether the supervisors check teachers' professional record for the purpose of the supervision of curriculum implementation. The result obtained was got was from the interview schedules and the questionnaires. The investigator realized that checking of the professional records was the only way to know whether the supervision of curriculum implementation is taking place in the public primary schools in Rongo Sub-County. Checking of teaches professional documents influence the supervision curriculum implementation. This in line with Eshiwani (1983) who stated that the supervisors have the responsibility of ensuring that the staff and the community are satisfied with the daily functioning of the school. These findings were as indicated in the figure 4.4. 


\section{Teachers' professional records}

The graph bellow shows the results of checking teachers' professional records and how the professional records were kept by the teachers

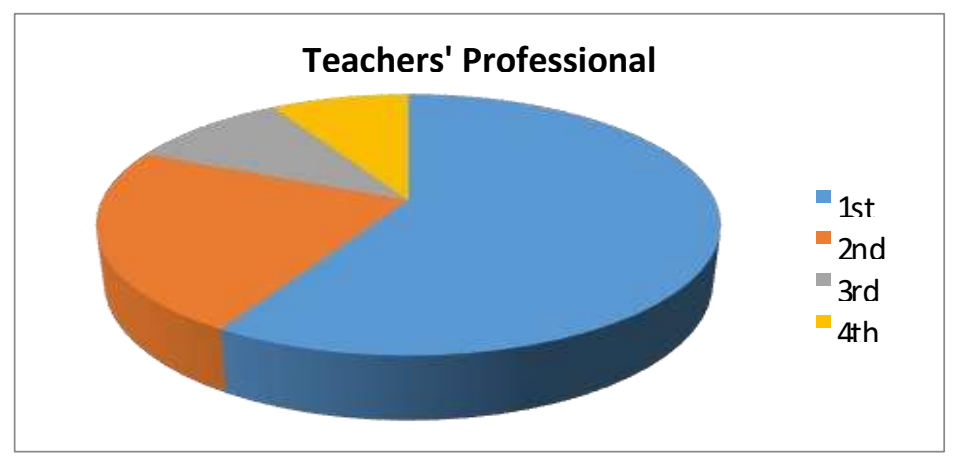

The figure 4.5 clearly indicated that $100 \%$ of the CSOs, $71.5 \%$ of the head teachers, $100 \%$ of the deputy head teachers accept that they carry out the supervision by checking the professional records and when the class four teachers were asked whether their professional records were being checked, $88.6 \%$ accepted while $11.4 \%$ reported that their professional records are being checked rarely. Checking of teacher's professional documents affects the implementation of the curriculum. This is in line with Eshiwani (2005) who stated that supervision has the responsibility of ensuring that the staff and the community are satisfied with the daily function of the school. The findings show rightly that the supervisors carry out their work of supervision as can be seen in the percentages in figure 4.4. These findings are in line with Bradil (1987) who stated that effective supervisors are those who are constantly involved in checking of the teachers' professional records.

\section{Response on Checking Teachers' Professional Records}

Fifty-seven head teachers representing $81.4 \%$ indicated that they supervise curriculum implementation in class four through the deputy head teachers because the deputy head teachers are the ones who are directly in charge of curriculum implementation, but they can occasionally visit these classes and see what takes place. All the 5 CSO which represent $100 \%$ said that they do not specifically go for class four but may visit this class once they are through with Tusome and Egma which seem to be their main concern. Eighty-nine class four teachers representing $68 \%$ reported that the supervisors rarely visit their classes. The findings show clearly that the supervisors do monitor the progress of the learners. These findings are in line with Braidol (2013) who stated that effective supervisors are those who are constantly involved in checking the teachers' professional records.

In addition, the researcher sought to know whether the supervisors check the class four teachers' professional records, 76 class four teachers which represents $58.5 \%$ reported that they don't check the teachers' professional records while 38 of them who represent $29.2 \%$ indicated that they sometimes check teachers' professional records and the remaining 16 represent $12.3 \%$ said they do check the professional records.

Seventy-seven deputy head teachers who represent $96.3 \%$ reported that they check the professional records, when they were asked whether they carryout lesson observation, they all responded that they do with exceptional cases where they can assign the senior teachers to carryout class lesson observation. On checking the professional records, all the deputy head teachers said they do but $56(72 \%)$ reported that they check the professional records monthly while 21 (16.2\%) responded that they check the professional records weekly. This statistic shows that the head teachers are not aware of the syllabus coverage in class four because they rarely check the professional records of teachers and they believe that it's the work of the deputy head teachers. On the other hand, it can be concluded that the deputy head teachers are closely monitoring the professional documents and are in control of what goes on in class four.

The research also sought to find out whether the CSO, head teachers and the deputy head teachers check the pupils lesson notes, it was realized that 68 head teacher which represent $97.1 \%$ do not check the pupils lesson notes, 69 deputy head teachers representing $89.6 \%$ also reported that they do not check the pupils exercise books because of the workload but they do check the teachers lesson notes. This is clear that both the head teachers and the deputy head teachers do not know what the class for pupils are writing and so they cannot defend what is going on in class four and are not able to make any correction or give direction as pertains to the pupil's exercise books. 


\section{Lesson observation}

\begin{tabular}{lccccccccc}
\hline Frequency & CSOs & & \multicolumn{2}{c}{ Head teacher } & \multicolumn{2}{c}{ D/Head teacher } & \multicolumn{2}{c}{ Class four } \\
& F & $\%$ & F & $\%$ & f & $\%$ & F & $\%$ \\
& & & & & & & & \\
\hline Termly & 5 & 100 & 4 & 5.7 & 5 & 6.5 & 30 & 23.1 \\
Monthly & & & 66 & 94.3 & 72 & 93.5 & 92 & 70.8 \\
Weekly & & & & & & & 8 & 6.1 \\
Never & - & - & - & - & - & - & - & - \\
\hline Total & $\mathbf{5}$ & $\mathbf{1 0 0}$ & $\mathbf{7 0}$ & $\mathbf{1 0 0}$ & $\mathbf{7 7}$ & $\mathbf{1 0 0}$ & $\mathbf{1 3 0}$ & $\mathbf{1 0 0}$
\end{tabular}

The activity of class observation is supported by Okumbe (1988) in his research on effective supervision and inspection when he stated that the roles of the head teachers or supervisors are to observe live lessons regularly and hold conferences with the teachers, guide them on the curriculum and the lesson plans. This is also supported by Goldhammer et al. (1980) who portray supervision as an activity in which education administrators express leadership in the improvement of teaching and learning. Classroom observations correct methodology alerts teachers on the preparation and delivery of content.

\section{Lesson observation}

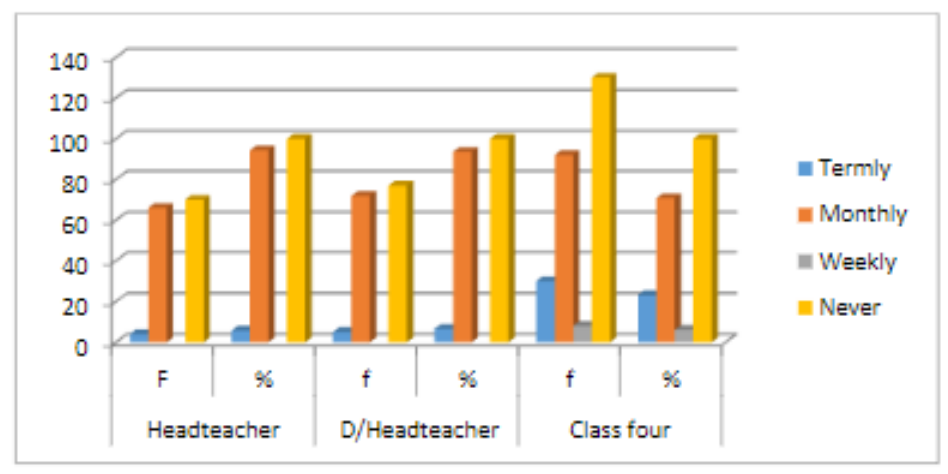

In table 4.8 and figure 4.5 , the researcher sought to find out the frequency of lesson observation by the head teachers and the deputy head teachers. Class four teachers were also asked how frequently the supervisors visit their classes for lesson observation. Ninety-Four point three per cent $(94.3 \%)$ of the head teachers said that they conduct lesson observation monthly and $5.7 \%$ of them said that they conduct lesson observation termly. This means that a greater percentage of the head teachers agree that they do conduct lesson observation. Ninety-three point five per cent

$(93.5 \%)$ of the deputy head teachers reported that they carryout lesson observation monthly while $6.5 \%$ of them said that they conduct lesson observation termly. When the class four teachers were asked whether head teachers and the deputy head teachers carry out lesson observation in their classes, $70.8 \%$ of them reported that the lesson observations were carried out Monthly and 23.1\% reported that the lessons were being observed termly and only $6.1 \%$ reported that the lessons were being observed weekly. A bigger percentage of class four teachers agree that the head teacher and the deputy head teacher conduct lesson observation monthly. It can be concluded that the supervisors carry out classroom lesson observation. This could help them monitor the implementation of the curriculum in class four.

The researcher also sought to find out whether conducting lesson observation affects curriculum implementation. He found that it affects curriculum implementation to a greater percentage because it allows the teachers to realize their areas of weaknesses and strengths for correction, improvement and motivation. He also said that lesson observation keeps teachers on toes so they keep on preparing because they do not know when they may be observed or visited in class.

The researcher also sought to find out whether the teachers were informed before they were observed and whether the head teachers, deputy head teachers and the CSO gave the feedback on the observed lesson. It was found that they inform teachers earlier to give them time for preparation and after observing a lesson, they sit with the individual teachers to discuss on the observed lesson. When the class four teachers were also asked whether they were informed before lesson observation, they accepted and also said that there were discussions after the lesson observation. This activity was supported by Okumbe's (1988) research on effectiveness of supervisors and inspectors. He found out that the role of the supervisors (the head teachers and the deputy head teachers) was to observe lessons and hold conferences with teachers who guide the lessons and the curriculum. This was also supported by Goldhammer et al., (1980) who portrayed supervision as an activity in which supervisors or education administrators' express leadership in the improvement of teaching and learning. 
Eshiwani (1993) attributes poor performance of public school learner's to head teachers who do not know what takes place in classrooms. Griffins (1994) argued that head teachers need to observe their teachers on a regular basis, make notes in the classrooms and work with commitment to discuss their observations promptly with the teachers in order to improve on content delivery and methodology.

\section{Checking pupils' notes}

\begin{tabular}{lcccccc}
\hline & \multicolumn{2}{c}{ Head teacher } & \multicolumn{2}{c}{ D/Head teacher } & \multicolumn{2}{c}{ class four } \\
Frequency & $\mathrm{F}$ & $\%$ & $\mathrm{f}$ & $\%$ & $\mathrm{f}$ & $\%$ \\
\hline Rarely & 5 & 7.1 & 14 & 18.2 & 47 & 36.2 \\
Sometimes & 12 & 17.1 & 61 & 79.2 & 71 & 54.6 \\
Never & 53 & 75.7 & 2 & 2.6 & 912 & 9.2 \\
\hline Total & $\mathbf{7 0}$ & $\mathbf{1 0 0}$ & $\mathbf{7 7}$ & $\mathbf{1 0 0}$ & $\mathbf{1 3 0}$ & $\mathbf{1 0 0}$
\end{tabular}

The researcher sought to find out the frequency of checking pupils' lesson notes or pupils note books. Seventy-five point seven per cent $(75.7 \% /)$ of the head teachers reported that they never take time to check the pupils lesson notes because of lack of time $12(17.1 \%)$ reported that they sometimes check pupils lesson notes. Sixty-one (79.2\%) deputy head teachers said that they sometimes check the pupils lesson notes and $14(18.2 \%)$ reported that they rarely check the pupils lesson notes. Seventy-one class four teachers were also asked whether the head teachers and the deputy head teachers check their pupils' note books, $54.6 \%$ of them reported that the head teacher and the deputy head teacher sometimes check the pupils' lesson notes while $36.2 \%$ of them said that the head teachers and their deputies rarely check the pupils' lesson notes. From these results, it is a clear indication that both the head teachers and the deputy head teachers do not check the pupils lesson notes as frequently as required hence are not in control of what the learners of class four are writing and cannot therefore give correction on wrong areas and cannot appreciate the good work by the teacher in the implementation of curriculum and the pupils in the acquisition of knowledge skills and attitude expected of them from the implementation of the curriculum.

These findings are in line with Hallinger and Hecks (1998) in their finding that there is a significant impact on checking learners' exercise books and their performance. Williams (2003) also stated that there is a significant impact on checking pupils note books for efficiency in curriculum implementation hence high performance in classes. These findings also differ with Fire Stom and Rieh (2008) who expressed that checking of student notebooks or exercise books does not have direct effect on students' performance; notes are mediating influence on teachers' instruction, communication and school organization leading to high performance.

\section{The influence of the roles of CSOs, Head teachers and Deputy Head teachers}

The CSOs, the head teachers and the deputy head teachers reported that they have several roles in the supervision of curriculum implementation in public primary schools and especially in class four. When the CSOs were asked, they reported that their work included visiting schools to support teachers in their teaching methodology, organize for seminars to help refresh teachers on the new methodology and other immerging issues in education They are also to report to the teacher's employer (TSC) about the staffing situation on the ground for possible balancing. The

CSOs also check the syllabus coverage among other duties as assigned by the TSC sub-county director. The head teachers are the representatives of the TSC on the ground. They are chief executive officers in schools. The head teachers are charged with the responsibility of clarifying the policy from the TSC. They check the professional records of teachers, hold class lesson model for teachers, provide teaching learning resources, check the pupils note books, promote teachers professional development plans, assigning duties to the deputy head teachers and other responsibilities and duties as assigned by the Sub-County Education Director. The deputy head teacher assumes full responsibilities of the head teachers in absence. They are directly in charge of curriculum implementation and discipline in the school.

\section{REFERENCES}

[1].Beacher Report, (1948), Education Commission. Government Printer.

[2].Blaze, J. \& Blaze, J. (1999), Handbook of instructional leadership.Chanyalew.

[3].Blaze, J. \& Blaze, J. (2000), Empowering teachers, what successful principals can do (2 ${ }^{\text {nd }}$ edition) thousand Oak C.A.

[4].Cohen, L. (1994). Research methods in education ( $4^{\text {th }}$ edition). New York.

[5].Cohen, L. (1994). Research methods in education ( $4^{\text {th }}$ edition). New York.

[6].Cohen, M. (2000). Foundational approach in school administration. New York: McGraw Blaze,

[7].J. \&Blazé, J. (1999), Effective instructional leadership through the learner's eye. Thousand Oak C.A. Corwin.

[8].Cohen, M. (2000). Foundational approach in school administration. New York: McGraw Hill Publishers

[9].Eshiwani, (1983). Access without success some reflection on the achievement in education in the western Kenya province.

[10]. Eshiwani, G., (1993). Education in Kenya since independence: Nairobi: East African Education Publishers. first track initiative. Washington D.C World Bank. 
[11]. Glickman, C.D. and Gordon, S.P., (1990). Supervision of instruction. A developmental approach. (2 $2^{\text {nd }}$ Edition). Boston: Allyn and Bacon.

[12]. Gold Hammer, (1980). Clinical supervision (2 ${ }^{\text {nd }}$ edition) New York.

[13]. Gold Hammer, (1980). Clinical supervision ( $2^{\text {nd }}$ edition) New York.

[14]. Goldhammer, R. Anderson, R.H and Krajewiski R.J., (1980). Clinical supervision (2 ${ }^{\text {nd }}$ edition). New York: Holt Rinehart and Winston.

[15]. Goldhammer, R. Anderson, R.H and Krajewiski R.J., (1980). Clinical supervision (2 ${ }^{\text {nd }}$ edition). New York: Holt Rinehart and Winston. Hill Publishers.

[16]. IIEP / UNESCO (2007). Education for all a moving largest. Paris

[17]. Kerio, C.M. (2014) An analysis of Principals Effectiveness in selected supervisory practices and teacher attitude towards the practices in public primary schools in Kericho District.Unpublished project Nairobi University

[18]. Kerio, C.M. (2014) An analysis of Principals Effectiveness in selected supervisory practices and teacher attitude towards the practices in public primary schools in Kericho District. Unpublished project Nairobi University.

[19]. Kerlinger, F.N. (1979). Behavior-research: a conceptual Approach: New York: HOLT.

[20]. Kerlinger, F.N. (1979). Behavior-research: a conceptual Approach: New York: HOLT.

[21]. Koech Report (1999). Report of the education commission of enquiry in educational system of Kenya. Totally Integrated Quality Education. Nairobi: Government Printers

[22]. Koech Report (1999). Report of the education commission of enquiry in educational system of Kenya. Totally Integrated Quality Education. Nairobi: Government Printers.

[23]. Kothari, (2005). Element of Education and Social Sciences: Research methods. Nairobi, Mesole Printers.

[24]. Kothari, (2005). Element of Education and Social Sciences: Research methods. Nairobi, Mesole Printers.

[25]. Kothari, (2005). Element of Education and Social Sciences: Research methods. Nairobi, Mesole Printers.

[26]. Kothari, (2006). Research methodology and techniques (2 ${ }^{\text {nd }}$ edition). Pearson Education, Newcastle Ravet Publication.

[27]. Kothari, (2006). Research methodology and techniques (2 ${ }^{\text {nd }}$ edition). Pearson Education, Newcastle Ravet Publication.

[28]. Kothari, (2006). Research methodology and techniques (2 ${ }^{\text {nd }}$ edition). Pearson Education, Newcastle Ravet Publication.

[29]. Kothari, (2008). Impact of School Supervision on School Performance. Nairobi: Mesole Printers.

[30]. Kothari, (2008). Impact of School Supervision on School Performance. Nairobi: Mesole Printers.

[31]. Kothari, (2008). Impact of School Supervision on School Performance. Nairobi: Mesole Printers.

[32]. Ministry of Education (2009). Teacher proficiency course training manual; NRB Ministry of Education.

[33]. Ministry of Education Science and Technology (2000). School management guide. Nairobi: Government Printer.

[34]. Ministry of Education, (2004). School empowerment programme for primary school teachers, head teacher module Nairobi: Ministry of Education.

[35]. MoE, (1994). School empowerment programme for primary school's head teachers and teacher's module. Nairobi: Government Printer.

[36]. MoE, (2002). Decentralized management of education in reference manual. Nairobi Government Printer.

[37]. Mugenda and Mugenda, (2003). Research methods: Qualitative and quantitate approach. Nairobi: Act Press.

[38]. Mugenda, M.O and Mugenda, A.G (2003). Research methods: Qualitative approaches. Nairobi: Act Press.

[39]. Mugenda, O.M and Mugenda A.G, (1999). Research methods, Qualitative and qualitative approach. Nairobi: Act Press.

[40]. Mugenda, O.M, and Mugenda, A.G, (2008). Research methods: Qualitative and quantitative approach. Nairobi: Act Press.

[41]. Ndegwa Commission, (1970). Public service structure and remuneration. Nairobi: Government Printer.

[42]. Ndegwa Report (1970). Public service structure and remuneration commission. Nairobi: Government Printer.

[43]. Ochieng, O. (2007). Effectiveness of TAC tutors in institutional supervision in primary Education: A case study of Lugari District Kenya. Kenyatta University unpublished M.ED Project.

[44]. Owoko, (2004). Instructional supervisory function of head teachers. Nairobi: Kenyatta Printers.

[45]. Owuoko, S. (2004). Instructional supervisory functions of the Head teacher in Public Schools Starche Division, Nairobi Kenyatta University unpublished M.Ed project.

[46]. Ozigi, O.A., (1983). Education in northern Nigeria. London: Atllan and Unwin Publishers.

[47]. Ozigil O.A., (1993), School Management. Nigeria: Macmillan Publishers.

[48]. Ozingi, A.O. (1983). Handbook of school administration and Management. Nigeria: Macmillan

[49]. Segiovani, T.J \&Starratt, R.J. (2007). Supervision ( $8^{\text {th }}$ Ed). New York: McGraw Hill Companies.

[50]. Sergiovani, T.J., \&Starratt, R.J. (1995). Definition of instructional supervision. New York: McGraw Hill Companies.

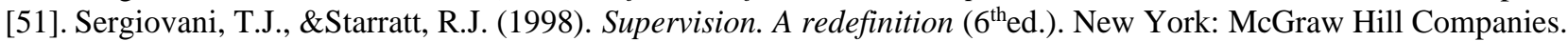

[52]. Sergiovani, T.J., T.J, and Slarratt, R.J. (2007) Supervision. A redefinition (3 ${ }^{\text {rd }}$ Ed). New York: McGraw Hill Companies.

[53]. Sergiovani. T.J., \&Stratrat, T.J., (1998). Supervision and management in education. New York: McGrew Hill.

[54]. Sogiovantis, T.J., \&Starratt, T.J., (2002). Supervision are definition (3 ${ }^{\text {rd }}$ edition) New York: McGraw Hill

[55]. Wanzare Z \& Da Costa J (2004). Rethinking instructional leadership roles of the school principals, challenges and prospects. Journal Educational Thought.

[56]. Wanzare, (2013). Instruction supervision in public primary schools. 
Journal of Advance Research in Education \& Litrature (ISSN: 2208-2441)

[57]. Wanzare, Z. (2012). Supervision in secondary schools and staff development. Journal Educational Thought. [58]. Wanzare, Z. (2015) Secondary school administration and learners' performance. Educational thought 